\title{
BÍLÁ HORA - BOJIŠTĚ TřICETILETÉ A STUDENÉ VÁLKY
}

\author{
MICHAL BUREŠ - LADISLAV RYTÍr
}

\begin{abstract}
Abstrakt: Detailní systematický archeologický výzkum prostoru Bílé Hory a nejbližšiho okoli posledních zhruba šesti let poskytuje celou řadu nových poznatků. Bílá Hora, obora Hvězda i park Ladronka na katastrech Břevnova, Liboce a Ruzyně v Praze 6 se ve světle archeologických nálezů ukazuje nejen jako dějiště památné bitvy na Bílé Hoře, ale také jako symbolické bojiště studené války. Zatímco třicetiletou válku reprezentuji nálezy součástí palných zbraní a zejména munice, studená válka po sobě na mistě ponechala pozůstatky ležení vojáků ČSLA účastnících se jedné z největšich propagandistických akci obdobi komunismu u nás, tzv. Československé spartakiády. Př́spěvek konfrontuje svědectví archeologických, písemných a ikonografických pramenů a pro 20. století též svédectví kolmých leteckých snímků.
\end{abstract}

Klíčová slova: Bílá Hora - bojiště - třicetiletá válka - spartakiáda.

\section{White Mountain: A Battlefield of the Thirty Years' War and the Cold War}

Abstract: Detailed and systematic archaeological research on the site of White Mountain (Bíla Hora) and its immediate surroundings in the last six years has yielded a great deal of new information. In the light of archaeological finds, White Mountain, the Hvězda game preserve and the Ladronka park in the cadastral zones of Břevnov, Liboc and Ruzyně in Prague 6 turned out to be not only the sites connected with the historic Battle of White Mountain but also a symbolic battlefield of the Cold War. While the Thirty Years' War is represented by the finds of firearms and, in particular, ammunition, the Cold War left traces in the form of an encampment of the Czechoslovak Army soldiers taking part in the Czechoslovak Spartakiad, one of the largest propaganda events of the communist period in this country. The paper compares evidence of archaeological, written and iconographic sources, and for the 20th century also the evidence of aerial photography.

Key words: White Mountain - battlefield - Thirty Years' War - Spartakiad.

\section{Úvod}

Archeologická data, která zpracovává předkládaný příspěvek, byla získána díky soustavně prováděnému monitoringu všech (tzn. i drobných) stavebních zásahů do povrchu vesměs urbánní krajiny Bílé Hory v letech 2008-2015. Jejich prostorově větší část náleží nově zakládaným a překládaným parkovým cestám a cyklostezkám. Menší část pak ploše čtyřech budov veřejného charakteru (bytové domy pro seniory a mateřská školka). Jednotlivé výzkumy a plochy výzkumů jsou zobrazeny na obr. 1.

Na základě analýzy starších archeologických vesměs negativních akcí v prostoru Bílé Hory jsme poprvé $\mathrm{v}$ roce 2008 přistoupili $\mathrm{k}$ předstihovému detektorovému průzkumu prostoru projektovaných tř́ bytových domů pro seniory v ulici Rozdělovská. Předstihovým průzkumem detektorem kovů bylo získáno celkem třicet artefaktů, z nichž čtyři byly olověné kule do palných zbraní. Naopak při následných zemních pracích spojených se stavbou bylo pod travnatým drnem dokumentováno intaktní podloží bez nálezů (Bureš ed. 2010). Tato zkušenost se potom opakovala nejen při zakládání a překládání parkových cest (Bureš ed. 2010a, 2010b; Rytír ed. 2015), ale i při dalších větších stavebních akcích, jako byla výstavba nové školky (Bureš ed. 2011) nebo rekonstrukce kamenné obvodové zdi obory Hvězda (Rytír ed. 2015a). Počínaje rokem 2008 jsme tak při záchranných výzkumech ve sledovaném prostoru věnovali zvýšenou pozornost předstihovým výzkumům detektorem kovů značky XP Gold Maxx Power, které na rozdíl od následného sledování případných výkopových prací opakovaně přinášely výsledky v podobě nových artefaktů.

V průběhu výzkumných kampaní let 2008-2015 byly v prostoru Bílé Hory zaznamenány čtyři výrazné skupiny nálezů. Dvě z těchto skupin je možné klást do vztahu k určitým historickým událostem. První výraznou komponentou jsou militaria z období třicetileté války, druhou 


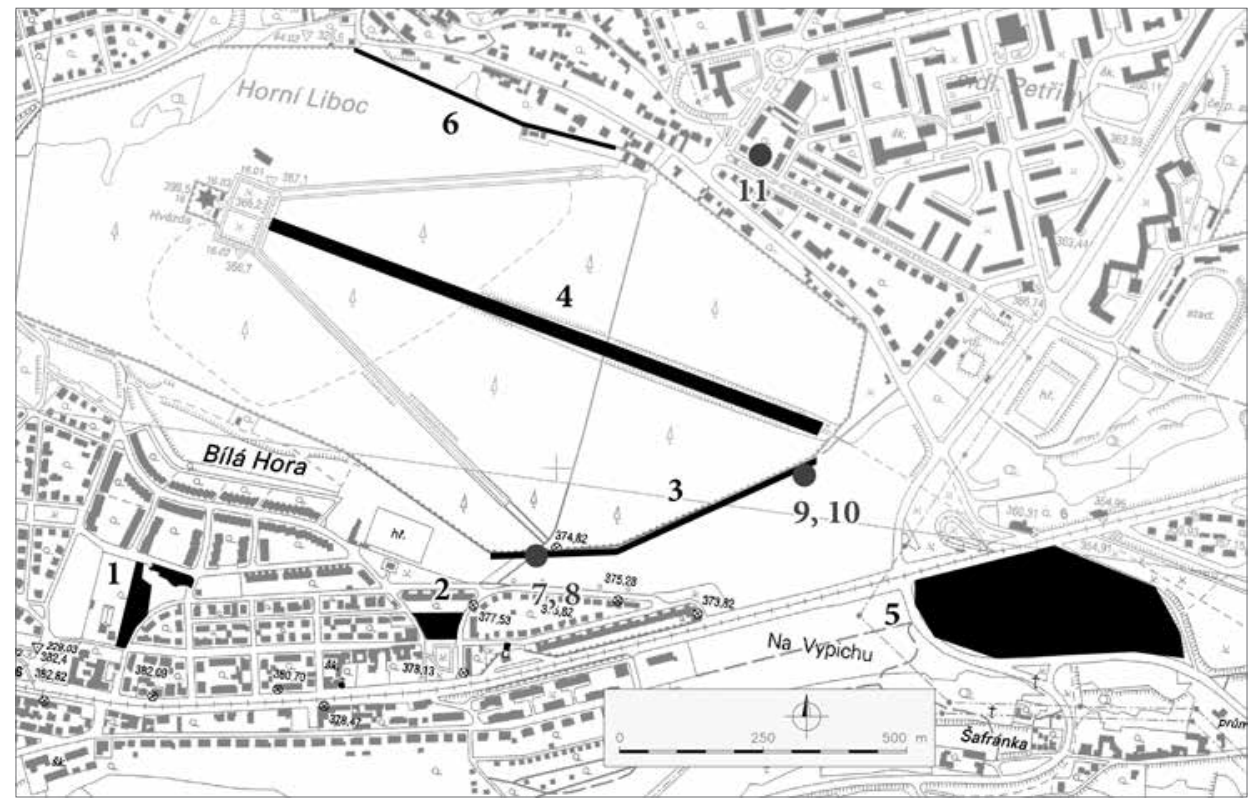

Obr. 1. Celkový plán zájmového území s vyznačeními plochami výzkumů. 1 - tři bytové domy pro seniory ul. Rozdělovská (výzkum 2008); 2 - novostavba mateřské školky v ul. Za Oborou (výzkum 2010); 3 - cyklostezka Markétská - Staré náměstí (výzkum 2010); 4 - obnova cestní sítě Hvězda (výzkum 2015); 5 - areál volného času Ladronka (výzkum 2010); 6 - rekonstrukce kamenné zdi v oboře Hvězda (výzkum 2015); 7 - záchranný archeologický výzkum na Bílé hoře - Praha-západ, 22. 4. 1955 (Smetánka 1967); 8 - výstavba spartakiádního městečka, 9 - výkopové práce Vojenské správy ČSLA (Mašek 1960); 10 - budování vojenského spartakiádního tábora; 11 - nález koster v Praze Břevnově, Zeyerova alej čp. 46.

Abb. 1. Gesamtplanskizze des Interressensgebietes mit eingezeichneten Grabungsflächen. 1 - Drei Seniorenwohnhäuser in der Straße Rozdělovská (Grabung 2008); 2 - Neubau des Kindergartens in der Straße Za Oborou (Grabung 2010); 3 - Margarethenradweg - Staré náměstí (Grabung 2010); 4 - Sanierung des Wegenetzes Hvězda (Grabung 2015); 5 - Freizeitareal Ladronka (Grabung 2010); 6 - Restaurierung der Steinmauer im Wildgehege Hvězda (Grabung 2015); 7 - archäologische Rettungsgrabung auf dem Weißen Berg - Prag-West, 22. 4. 1955 (Smetánka 1967); 8 - Errichtung des Spartakiadenstädtchens, 9 - Aushubarbeiten der Militärverwaltung der Tschechoslowakischen Volksarmee (Mašek 1960); 10 - Aufbau des Militärlagers für die Spartakiade; 11 - Skelettfunde in Prag Břevnov, Zeyerova alej Nr. 46.

komponentou jsou pozůstatky pobytu Československé lidové armády v dobách konání československých spartakiád. Další dvě části nálezového souboru jsou časově průběžné a není možno je vztáhnout k nějaké konkrétní události ani účelu. Nejrozsáhlejší část nálezového souboru je tvořena mincovními nálezy. V průběhu všech pojednávaných výzkumů bylo nalezeno a dokumentováno celkem 83 mincí z období od roku 1703 (grešle Leopoda I.) v podstatě do současnosti. Druhou skupinou nálezů podobného charakteru jsou nálezy nábojnic. Bylo nalezeno celkem 20 nábojnic. Nepodrobovali jsme je bližšímu zkoumání, nebot' při jejich zběžné prohlídce jsme usoudili, že se jedná o nábojnice z různých období. Mezi nimi jsou prokazatelně nábojnice z poplašných a loveckých zbraní. Nemůžeme je tedy spojit ani s jedním konkrétním účelem. Následující text se věnuje dvěma prve jmenovaným skupinám nálezů: militariím z období třicetileté války a nálezům souvisejícím s pobytem ČSLA.

\section{Historický a archeologický obraz oblasti Bílé hory v 17. století}

Systematický zájem o výzkumy bojišt', či obecněji o poznání vojenských konfliktů archeologickými metodami sahá v Čechách asi do poloviny 20. století. Prvním systematickým výzkumem bojiště $\mathrm{z}$ období trricetileté války byl však až výzkum bojiště u Třebele (okr. Ta- 
chov) z let 1988-1990 a 1999-2003 (Matoušek 2006). Mezi další zkoumaná bojiště se řadí oblast Volarských šancí (okr. Prachatice) na Zlaté stezce, kde bylo v prostoru polního opevnění z let 1618-1620 zachyceno množství militarií (Beneš-Kubů-Török 1995). Polní tábor švédské armády z let 1639-1640 u Staré Boleslavi byl poprvé zkoumán již ve 30. letech 20. století, avšak zásadní poznatky $\mathrm{k}$ jeho fungování, výstroji a výzbroji švédského vojska přinesly až nálezy získané z amatérských detektorových průzkumů na počátku 21. století (Waldhauser 2009). Bojiště u Rozvadova, kde se střetl v roce 1621 zbytek stavovské armády poražené na Bílé hoře s císařským vojskem, se stalo předmětem odborného zájmu v letech 2006-2011 a detektorový a sondážní výzkum též přinesl celou řadu militarií (Matoušek a kol. 2011; Matoušek 2013). Bitvě u Rakovníka z 27. října až 6. listopadu 1620, která byla jistou předehrou bělohorské bitvě, se komplexně věnoval výzkum z roku 2010 (Bitva u Rakovníka 1620, 2011).

Bílá hora a její okolí se v průběhu 17. století stala několikrát místem válečných událostí. Během sporů mezi Rudolfem II. Habsburským a jeho bratrem Matyášem tábořilo v oboře roku 1608 císařské vojsko zformované Janem Tserclaesem Tillym (Skála 2001, 5). Obora a letohrádek byly poničeny též při vpádu pasovského vojska do Čech a do Prahy v únoru roku 1611 (Skála 2001, 5; k tomu Forbelský 2006, 47-53). Nejvýznamnější historickou a vojenskou událostí, jež se tohoto území dotkla, byla bitva na Bílé hoře, která proběhla 8 . listopadu 1620. Události, které jí předcházely, stejně jako rozbor bitvy samotné zpracovává řada historických prací (např. Pekař 1921; Tapie 1936; Polišenský 1951; Uhlír 1998; Petráň 2004; Forbelský 2006; Matoušek-KösslŠimek 2010; Chaline 2013). Během saského vpádu do Čech prošlo přes Bílou horu saské vojsko vedené Janem Jiř́m z Arminu, které 15. listopadu 1631 obsadilo Prahu (Skála 2001, 6; k tomu Forbelský 2006, 492). O rok později postupuje stejnou cestou Albrecht z Valdštejna při dobývání Prahy ze saských rukou (Skála 2001, 6). Po vítězství u Saské Kamenice roku 1639 oblehli Švédové pod velením Johana Gustafssona Banéra Prahu. Obléhání bylo vedeno od Bílé hory a Břevnova, kde v oboře letohrádku měli obléhatelé tábořit. Obora se měla ocitnout pod palbou děl obránců (Skála 2001, 6). Pro nedostatek pěchoty a těžkého dělostřelectva bylo obléhání ukončeno. Na konci války v roce 1648 oblehly Prahu švédská vojska stahující se od Brna pod velením Jana Kryštofa Königsmarcka, ke kterému se ještě přidal generál Wittenberg a posléze i Karel Gustav, následník švédského trůnu. Část těchto armád tábořila i v oboře letohrádku Hvězda, který byl značně poškozen (Skála 2001,6). Bílé hory a letohrádku se dotkly i další válečné události v následujících staletích (Skála 2001, 7-13).

Archeologové se v minulosti věnovali terénnímu výzkumu bojiště v oblasti Bílé hory náhodně, výhradně v souvislosti s výstavbou infrastruktury spartakiádního městečka Československé lidové armády v 60 . a 70 . letech 20 . století. Tyto záchranné výzkumy dokumentovaly asi čtyři výstavbou poškozené hromadné hroby v prostoru mezi jižním a hlavním vstupem do obory letohrádku Hvězda a na severní straně obory v ulici Zeyerova alej (obr. 1:7-11). Mezi artefakty pocházejícími ze zmíněných hromadných hrobů jsou mimo jiné čtyři kulky o průměrech 10,11 , 12 a $16 \mathrm{~mm}$, součásti vojenské výstroje (přezky, háčky, spínadla) a meč. I přes nedostatečnou dokumentaci hrobů a celé nálezové situace v terénu byla získána důležitá antropologická zjištění učiněná na kosterních pozůstatcích. Antropologický výzkum dokumentoval sečná a bodná zranění především na horní polovině těl, kdy údery byly vedeny shora, a dále pak střelná zranění z palných zbraní menších ráží. To by napovídalo zraněním způsobeným jízdou na pěšácích (Havel 1980; Janská 1966; Mašek 1960; Smetánka 1967).

Všechny uvedené výzkumy se nacházejí v místech, kde se 8 . listopadu 1620 zhruba rozložilo pravé křídlo stavovské armády pod velením knížete Kristiána Anhalta. Vzhledem k tomu, že se jednalo o největší bojový střet na daném území, alespoň rámcově zde popisujeme rozložení části soupeřících armád. Výchozí postavení a průběh bitvy detailně popisuje například Josef Petráň (1972) či Dušan Uhlíř (1998). Zaujaté postavení bylo v prostoru dnešního sídliště Řepy II (zhruba v okolí kř́ížení ulic Makovského a Slánské) a jižní zdi obory letohrádku Hvězda. Zhruba mezi současným památníkem bitvy a zdí obory operovaly čtyři jízdní a dva pěší útvary a byl zde umístěn uherský štáb Gasparda Konise. V prostoru obory byla ještě umístěna stavovská záloha složená z Anhaltova pěšího pluku, výmarského pluku a jízdy královské gardy. Na pravém křídle 
stavovského vojska a v zálohách se odhaduje ca 4740 mužů. Tuto sestavu ještě doplňovala asi tři děla (Uhlír 1998, 124-128).

Proti nim stála, tísněna Litovickým potokem, ligistická armáda tvořená würzburskou a lotrinskou tercií, v druhém sledu jezdeckými pluky Krazeho, Eynettenta a lotrinským plukem, ve třetím sledu třemi terciemi (Haslangův a Sulzův pluk, Schmidtův a Rouvillův pluk, pluk Herliberg). Poslední čtvrtý sled tvořila opět jízda. Síla ligistické armády se odhaduje na 12-13 tisíc mužů (Uhlír 1998, 126-129).

Bitva začala na levém křídle stavovské armády. Pravé křídlo zasáhlo do boje zhruba v druhé půli bitvy, kdy už se levé kř́idlo hroutilo a stavovské vojsko zůstalo prakticky bez velení. Po několika menších, převážně jezdeckých šarvátkách se i pravé křídlo dalo na ústup. V poslední fázi bitvy zůstala na pravém kř́ídle (zatlačená ke zdi obory) hornorakouská pěchota a moravský pěší pluk, ke kterým se stáhl Thurnův pěší pluk. Jako poslední zůstal na bitevním poli na stavovské straně v obklíčení bojující moravský pěší pluk pod velením hraběte Šlika, který však byl početní převahou Valonů, Neapolitánů a ligistické jízdy téměř zdecimován. Zbytek stavovské armády prchal z bojiště ku Praze přes Břevnov a Motol a Košíře. V oboře ještě zůstal výmarský jezdecký pluk a královská garda, jejichž vojáci byli ponecháni bez informací o vývoji bitvy a téměř zcela pobiti (k tomu Chaline 2013, 162-218; Uhlír 1998, 130-145).

Na sledovaném území tak nedošlo k nejintenzivnějším střetům, ovšem zvláště u střetu moravského pěšího pluku s císařskými a ligistickými pluky je nutné předpokládat značné bojové nasazení. O rozsahu předcházejících a následujících vojenských operací z let 1608-1648 nemáme zdaleka tak detailní informace.

Největší skupinu mezi nálezy zachycenými referovanými výzkumy tvoří kule do mušket, či jiných zepředu nabíjených zbraní. Jejich ráže se pohybují od 12 do $19 \mathrm{~mm}$ s váhou od 5 do $27 \mathrm{~g}$

\begin{tabular}{|c|c|c|c|c|c|}
\hline Výzkum č. & inv. č. nálezu MMP & průměr mm & váha $\mathrm{g}$ & materiál & poznámka \\
\hline 77/10 AP & 379.106 & 14 & 15 & olovo & \\
\hline $77 / 10 \mathrm{AP}$ & 379.107 & $16-16$ & 12 & olovo & deformovaná \\
\hline 77/10 AP & 379.109 & $17-19$ & 23 & olovo & deformovaná \\
\hline 77/10 AP & $379.116-117$ & $15-18$ & 3 & $\mathrm{BK}$ & kule?, deformovaná \\
\hline 39/08 AP & 378.507 & 15 & 15 & olovo & \\
\hline 39/08 AP & 378.508 & 17 & 24 & olovo & \\
\hline 39/08 AP & 378.509 & $15-18$ & 27 & olovo & deformovaná \\
\hline 39/08 AP & 378.512 & 15 & 26 & olovo & deformovaná \\
\hline 75/15 AP & 707.018 & 16 & 23 & olovo & \\
\hline 75/15 AP & 707.035 & 11 & 6 & olovo & neupravená \\
\hline $75 / 15$ AP & 707.040 & 16 & 5 & olovo & deformovaná \\
\hline 75/15 AP & 707.076 & 16 & 24 & olovo & \\
\hline 75/15 AP & 707.096 & 13 & 10 & olovo & \\
\hline 75/15 AP & 707.098 & 16 & 23 & olovo & \\
\hline 75/15 AP & 707.126 & 12 & 9 & olovo & \\
\hline 75/15 AP & 707.132 & 12 & 9 & olovo & \\
\hline $75 / 15$ AP & 707.139 & 15 & 15 & olovo & neupravená \\
\hline 91/15 AP & 707.177 & 72 & 1394 & $?$ & dělo \\
\hline
\end{tabular}

Tab. 1. Přehled nálezů kulí.

Tab. 1. Übersicht der Kugelfunde. 

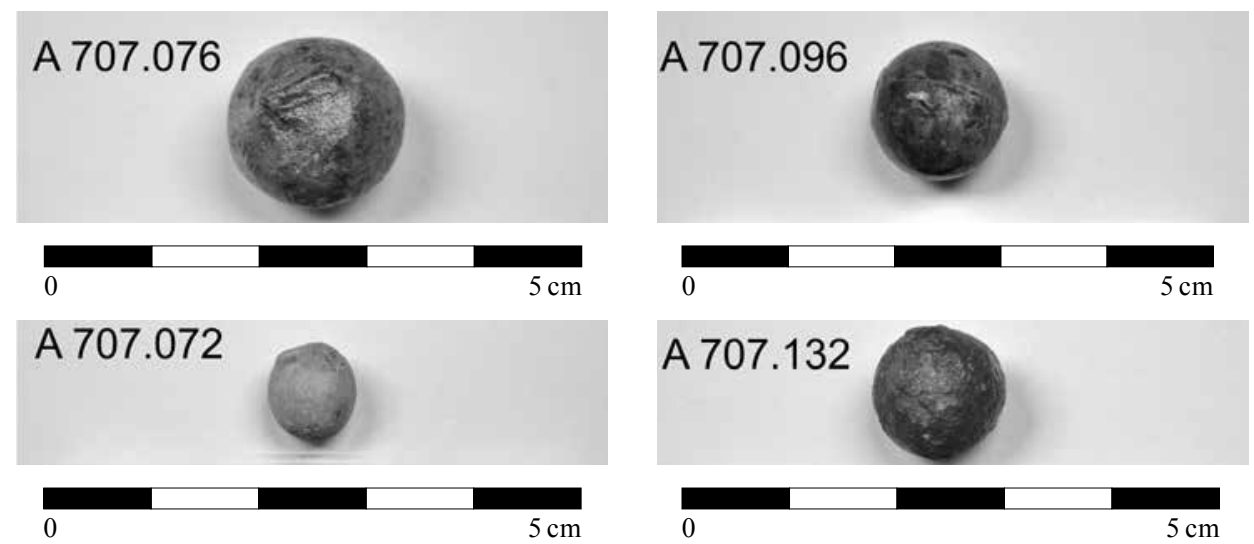

Obr. 2. Kule do předovek. Nálezy jsou identifikovány inventárními čísly Muzea hlavního města Prahy (viz tab. 1). Abb. 2. Vorderladerkugeln. Die Funde werden anhand von Inventarnummern des Museums der Haupstadt Prag identifiziert (siehe Tab. 1).

(obr. 2, tab. 1). Z toho dvě kule jsou neupravené (obr. 3) a pět vystřelených, či jinak deformovaných (obr. 4). Další nálezy jsou tvořeny knoflíky, zlomky kování a různými sponami, které by mohly být součástí výstroje soudobých vojáků (obr. 5). Při rekonstrukci severní (severovýchodní) zdi obory byla také zachycena železná kule, pravděpodobně do lehčího tříliberního polního děla - falkonetu, nebo plukovního děla s průměrem $72 \mathrm{~mm}$ a váhou $1394 \mathrm{~g}$ (obr. 6; k tomu Skalník 2012, 15).

Ráže zachycených kulí do palných zbraní odpovídají i popisu a průběhu bitvy, kdy na pravém křídle docházelo především k potyčkám jízdy a v závěru k pronásledování stavovského vojska taktéž hlavně císařskou a ligistickou jízdou. Jízda používala převážně dlouhé jezdecké pistole s kolečkovým zámkem, jejich ráže se pohybovala zhruba v rozmezí $10-13 \mathrm{~mm}$. Další jezdeckou zbraní byla arkebuza s ráží zhruba kolem $15 \mathrm{~mm}$. Muškety pěchoty měly ráži od 17 do 25 mm, nejobvykleji však 18-20 mm (Klučina 2000, 81; Matoušek 2006, 135-136; Šámal 2011, 54). Obvyklý průměr kulí u holandských, francouzských a anglických mušket se pohyboval mezi 16,5 a 17,5 mm (Mandzy 2015). Ráže kulí zachycených při námi prováděných výzkumech uvádí tabulka 1 .

Soubor zachycených kulí téměř rovnoměrně postihuje spektrum ráží soudobých zbraní. Je tak v souladu s dobovými popisy bitvy, které jezdecké šarvátky umist'ují především na pravé křídlo stavovské armády do prostoru jižně a jihovýchodně od ohradní zdi obory (obr. 1:1, 2) a následné boje pěchoty a decimování ustupujících či obklíčených jednotek u samotné zdi obory (obr. 1:2, 3). Nálezy pocházející z prostoru obory pak mohou souviset s poslední fází bitvy, kdy byly $\mathrm{v}$ oboře obklíčeny a pobity nebo zajaty oddíly výmarského pluku a královské gardy (obr. 1:4), zatímco nález dělové kule můžeme dát spíše do souvislosti s obléháním Prahy v roce 1639 švédskou armádou (obr. 1:6). Obecně nelze vyloučit, že mezi nálezy jsou i kule do loveckých zbraní, které v té době měly oproti pěchotním mušketám menší ráži a blížily se tak ráži zbraní jezdeckých, a výše uvedená interpretace je tak jen jedna z možností, podle našeho soudu pravděpodobnější než ostatní. Totéž platí pro všechny prezentované nálezy militarií. Mohou samozřejmě přináležet kterékoliv vojenské události, která se v průběhu třicetileté války udála v popisovaném prostoru. Náš prŕíklon k souvislosti s bitvou na Bílé hoře 8 . listopadu 1620 je dán spíše rozsahem tohoto střetu než výpovědní možností získaných nálezů. 

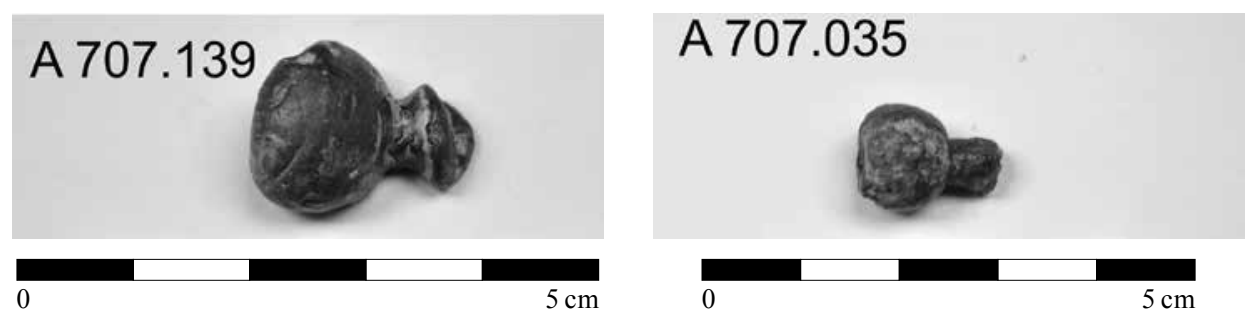

Obr. 3. Neupravené kule do předovek. Nálezy jsou identifikovány inventárními čísly Muzea hlavního města Prahy (viz tab. 1).

Abb. 3. Unbearbeitete Vorderladerkugeln. Die Funde werden anhand von Inventarnummern des Museums der Haupstadt Prag identifiziert (siehe Tab. 1).
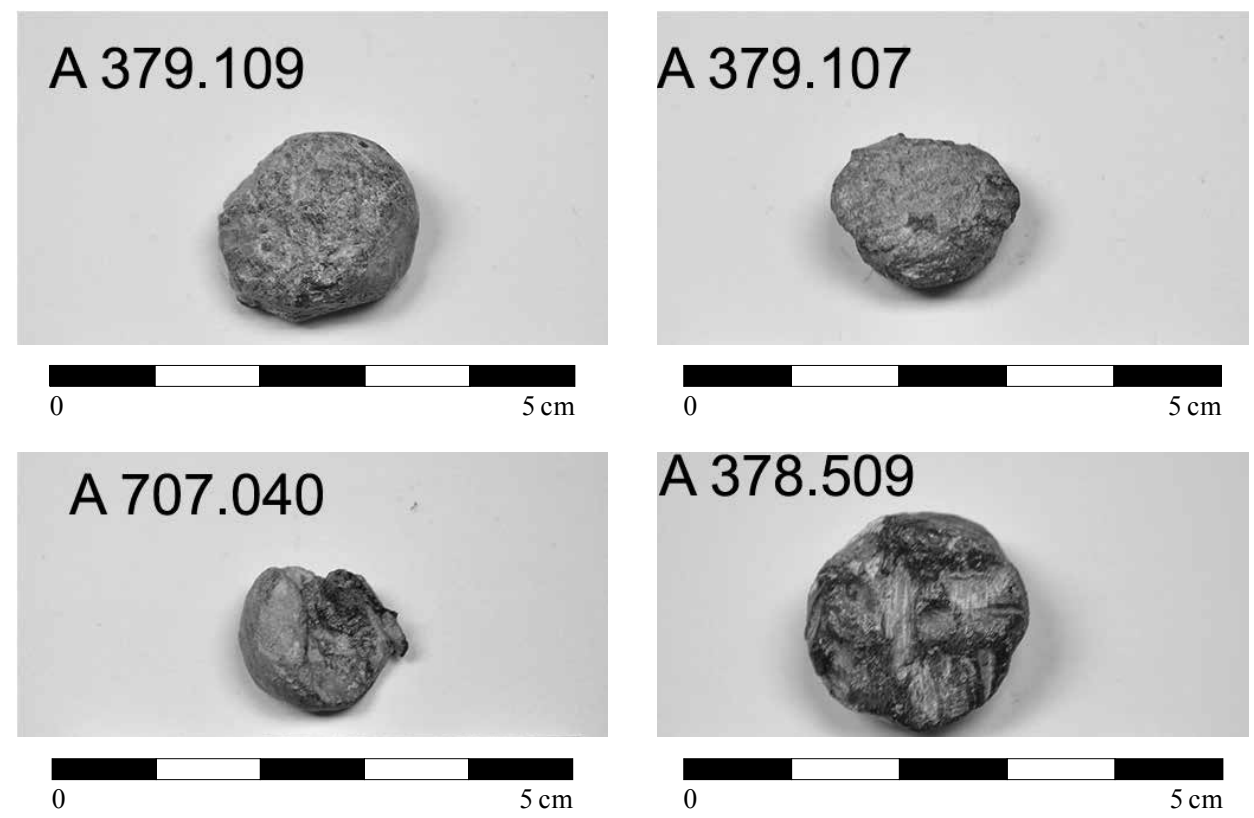

Obr. 4. Deformované kule do předovek. Nálezy jsou identifikovány inventárními čísly Muzea hlavního města Prahy (viz tab. 1).

Abb. 4. Deformierte Vorderladerkugeln. Die Funde werden anhand von Inventarnummern des Museums der Haupstadt Prag identifiziert (siehe Tab. 1).

\section{Československá spartakiáda - symbolické bojiště studené války}

Citované záchranné archeologické výzkumy 60. a 70. let nás dostávají ještě k jiné tematice, kterou je archeologie současnosti a studené války zejména. Diskuse nad pojetím archeologie nejnovějších období, které chronologicky následují archeologii postmedievální a nesouvisí s industrializací ani industriálními památkami, byla vedena $\mathrm{v}$ odborné literatuře již v 70 . letech 20. století. V současné anglosaské archeologické literatuře se lze setkat s termíny jako archeologie recentní minulosti nebo archeologie současné minulosti („recent past“ a „contemporary past“), přičemž tyto termíny mají odlišný význam (Holtorf-Piccini 2011; Harrison-Schoffield 2010). V české archeologické literatuře se doposud název pro archeologii nejnovějších období 

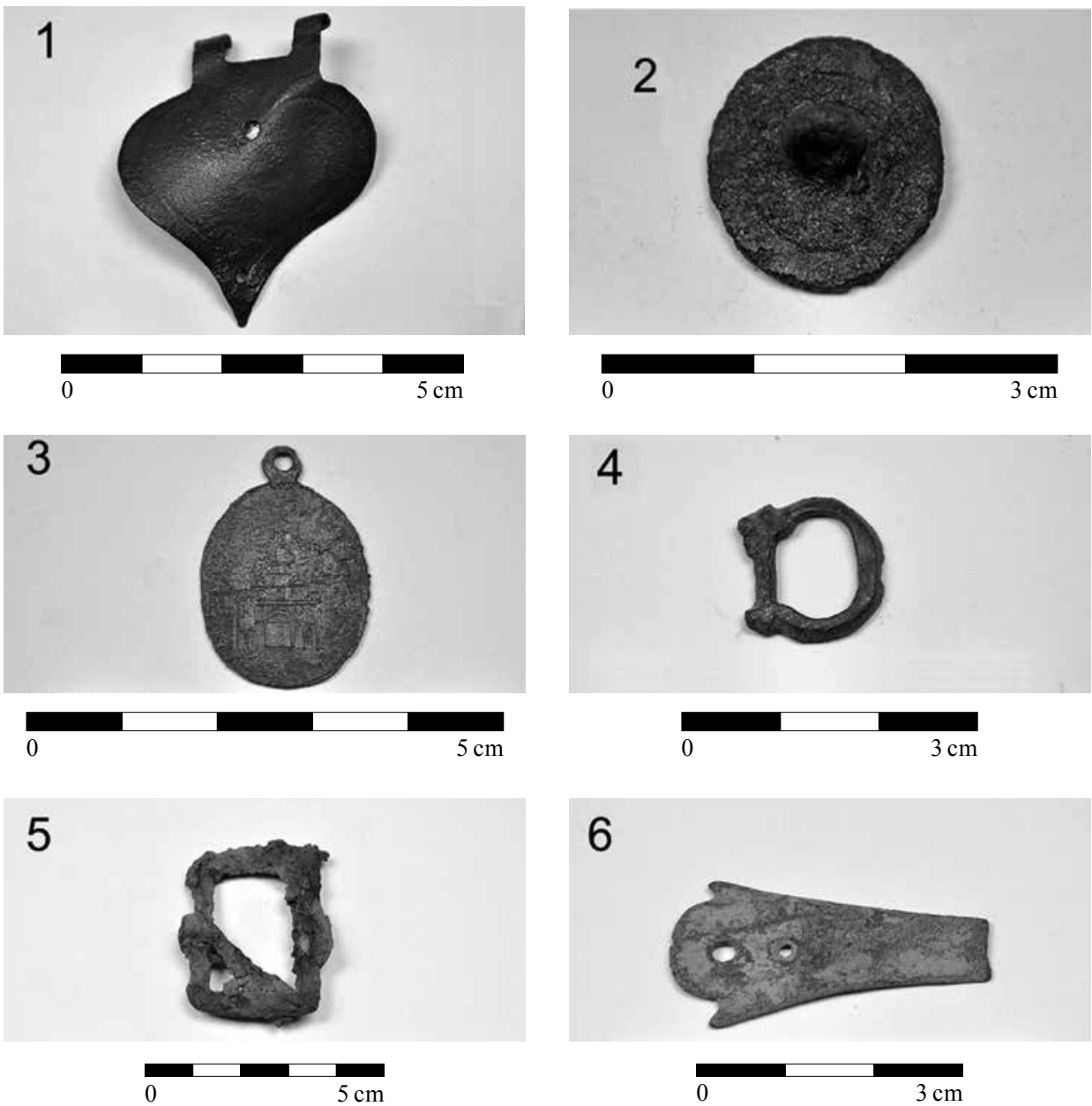

Obr. 5. Výběr z dalších metalických nálezů: 1 - kování?, inv. č. MMP A 707.169, plocha 4; 2 - knoflík, inv. č. MMP A 707.174, plocha 4; 3 - medailonek, inv. č. MMP A 707.112, plocha 4; 4 -zlomek přezky, inv. č. MMP A 378.513, plocha 1; 5 - železná přezka, inv. č. MMP A 379.223, plocha 2; 6 - zlomek kování, inv. č. MMP A 378.504, plocha 1.

Abb. 5. Auswahl weiterer Metallfunde: 1 - Beschlag?, Museum der Haupstadt Prag Inv.-Nr. A 707.169, Fläche 4; 2 - Knopf, Museum der Haupstadt Prag Inv.-Nr. A 707.174, Fläche 4; 3 - Medaillon, Museum der Haupstadt Prag Inv.-Nr. A 707.112, Fläche 4; 4 - Schnallenfragment, Museum der Haupstadt Prag Inv.-Nr. A 378.513, Fläche 1; 5 - Eisenschnalle, Museum der Haupstadt Prag Inv.-Nr. A 379.223, Fläche 2; 6 - Fragment eines Beschlags, Museum der Haupstadt Prag Inv.-Nr. A 378.504, Fläche 1 .

neustálil. Setkáváme se zde s termínem archeologie současnosti (poprvé Matoušek 2000), který v sobě vhodně snoubí pojetí anglosaské s možnostmi českého jazyka a zažitých termínů v domácím prostředí (Bureš 2015, 14). V poslední době se také poměrně často objevuje v domácí literatuře označení „archeologie modernity“ (Neustupný 2013, 13) pro tu část archeologické disciplíny, která zkoumá nedávnou minulost, resp. minulou současnost na podkladě archeologických pramenů tvořených moderními, nikoliv však současnými artefakty a ekofakty, které jsou mrtvé a němé (Neustupný 2013, 13). Zejména v souvislosti s archeologickým výzkumem občanské války ve Španělsku v druhé polovině 30. let 20. století se v literatuře také vyskytuje termín 


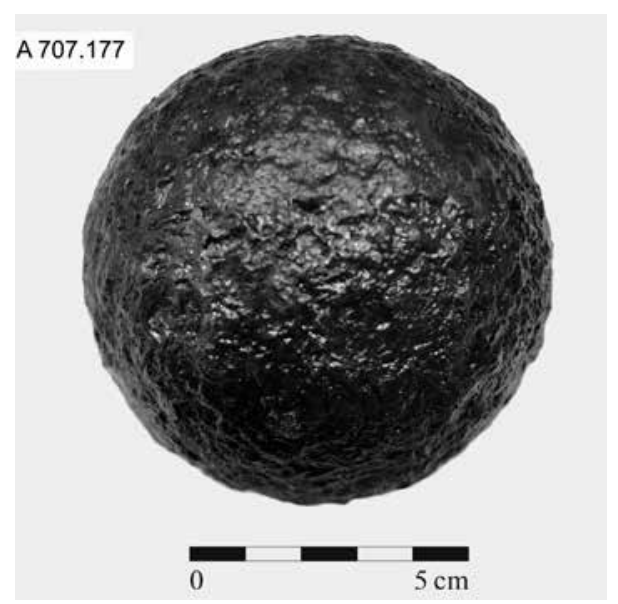

Obr. 6. Kule do falkonetu (viz tab. 1). Abb. 6. Falkonettkugel (siehe Tab. 1). archeologie supermodernity. Podle Gonzáleze-Ruibala $(2008,262)$ charakterizuje archeologii supermodernity superdestrukce a nakládání s traumatickou minulostí a vzpomínkami na konflikty. Doba následující po druhé světové válce je nazývána pozdní modernou nebo postmodernou, přičemž „pozdní moderna“ lépe vystihuje kontinuitu a návaznost na modernu. Pro postmoderní období je typické rychlé střídání technologických a sociálních změn, které neznáme z předchozích vývojových období lidstva (Harrison-Schoffield 2010, 7). Augé (1995, 26-30) považuje za typickou ,západní“ historickou zkušenost to, že 60., 70. i 80. léta se stala historií dříve, než skončila. Avšak jednou z hlavních charakteristik postmoderny je vysoce organizovaný nadnárodní kapitalistický korporativismus ovlivňující i kulturu (Harrison-Schofield 2010, 128). Podle této definice by se však země, jako je naše, staly

„postmoderními“ až někdy v 90. letech 20. století. Přesto však nejnovější české dějiny obsahují několik zlomů, které byly nuceně zapomenuty a staly se historií dříve, než mohly být prožity a dostatečně zaznamenány. Můžeme jmenovat např́íklad československou př́ípravu na ozbrojený konflikt na sklonku 30. let 20. století, zajištování československých hranic před uprchlíky z vnitrozemí v 50. až 80. letech 20 . století formou ženijně technických zátaras, tábory nucených prací období stalinismu atd. Vlastně celý poválečný vývoj, v němž Československo prožívalo dlouhá desetiletí, v nichž se jen těžko postřehnutelně stř́idala stagnace s úpadkem doplněná jednou invazí, spolu s dobou druhé světové války, je obdobím nesvobody, které zanechalo v dějinách celou řadu bílých míst, jež nelze zmapovat pomocí standardních písemných pramenů, a archeologie současnosti je schopna přinášet nové pohledy a poznatky. A konečně léta 1989-1990, která přinesla dalekosáhlé změny, které se tentokrát již ve zmíněném „západním“ duchu staly historií dřive, než plně odezněly. Současnost je však pojem, který je nezbytné na rozdíl od starších epoch stále aktualizovat a není jej možno vměstnat do nějakého chronologického rozpětí - hranice současnosti se stále posouvá s námi. Archeologie současnosti není archeologií určitého období jako například archeologie středověku. $Z$ tohoto pohledu se jeví užitečné současnost chronologicky určovat obráceně, tj. od současnosti do minulosti, do doby, která již přestala být prrítomností, tedy do doby, kterou jsme nezažili „my“ ani naši rodiče (Harrison-Schofield 2010, 5).

Archeologie studuje materiální kulturu, tedy to, co lidé po sobě zanechávají, z hlediska dlouhodobých procesů archeologické transformace. Tradiční archeologie pomocí svých metod, zejména klasifikace, tř́idění a tvorby logického řádu, vytváří z období neznámých a vzdálených, období známější a bližší, osvojuje si je. Archeologie současnosti zkoumá období, která (téměř) každý zná ze své vlastní zkušenosti, a pomocí stejných metod transformuje známé na odtažité, které je možné podrobit analýze (Buchli-Lucas 2001,9). Reverzní osvojení, vytváření ze známého neznámé umožňuje redukovat množství informací na informace relevantní. Zatímco tradiční archeologie získává informace z artefaktů, protože jiných zdrojů dat je nedostatečné množství, archeologie současnosti využívá artefaktů, aby artikulovala změt' stejně hlasitě znějících hlasů, kterými na nás promlouvá nedávná minulost (Buchli-Lucas 2001, 14). Na rozdíl od tradiční archeologie není hlavním metodologickým nástrojem archeologie současnosti terénní výzkum odkryvem. Subdisciplínu lépe charakterizuje povrchový průzkum využívající celou řadu dnes rozvinutých nedestruktivních archeologických metod. Důležitou součástí metody archeologie současnosti je fotografie (Harrison-Schofield 2010, 51), at' již fotografie dokumentující minulost, nebo fotografie postihující prŕiznaky reliktu zkoumaného předmětu. 
Nezanedbatelný je rovněž existencionální rozměr archeologie současnosti a její funkce terapeutická. Západní společnost epochy konzumerismu si připouští pomíjivost existence méně než její předchůdci. Archeologie současnosti tak připomíná, že věci vznikají a zanikají a materiální svět je pomíjivý. Studium artefaktů období nesvobody může působit terapeuticky na ty, kteří takové období osobně prožili, a tento prožitek v nich nechal nějaké neblahé následky (González-Ruibal 2008). Svoji úlohu zde sehrává i známá úloha artefaktů, které nelžou. Archeologie tak také vyplňuje prostor mezi tím, co lidé říkají, a tím, jak se chovají. Nejčastějšími tématy archeologie současnosti u nás jsou vesnice a obce z různých př́ícin zaniklé po roce 1945 (Bureš 2015; Fatková a kol. 2014; Funk 2013; Funk-Váňa 2012; Váňa 2016) a relikty opevnění státní hranice z let 1951-1989, pro které se vžilo označení „železná opona“ (viz dále).

Název tohoto př́íspěvku implikuje jeho jednoznačné začlenění do rámce archeologické subdisciplíny, která se označuje jako archeologie konfliktu (srov. Schofield 2005; Rak 2014, 13). Jakkoliv se archeologie konfliktu zdaleka neomezuje jen na období soudobých dějin, pro archeologii současnosti je archeologie konfliktu téma časté, možná nejčastější. Archeologie konfliktu však neznamená pouze výzkum vojenských konfliktů, ale též politických, náboženských nebo ekonomických, přičemž dochované relikty jsou většinou pozůstatkem kombinace několika ze zmíněných skupin (Rak 2014, 10). U nás se setkáváme s výzkumy opevnění z období před druhou světovou válkou (Rak 2011) nebo z jejího průběhu, výzkumy sestřelených letadel (Rak 2014), táborů nucených prací nebo hrobů politických odpůrců. Výzkumy reliktů železné opony (Bureš 2013; Rak-Funk-Váňa 2012; Rak-Starková-Funk 2014) pak spolu s aktuálně pojednávaným tématem tohoto příspěvku náleží do archeologie studené války, která je rozvíjena zejména v anglosaském světě, ale také v Německu. V Německu je přirozeně ve středu zájmu Berlínská zed' (Feversham-Schmidt 2009), ale dokumentovány jsou např́klad i opuštěné sovětské vojenské základny na území někdejší NDR (Boulton 2009). V Anglii byla na počátku třetího tisíciletí provedena rozsáhlá inventura a klasifikace materiálního dědictví studené války. Tento inventár̆, který by v listopadu 1989 obsahoval ca 8000 položek, ale jejichž počet se v následujících desetiletích výrazně ztenčil, zahrnuje radarové stanice, protiletecké pozorovatelny a dělostřelecké baterie, raketová sila, podzemní kryty i sklady civilní obrany (Cocroft 2009, 108, 112). Většina památek tohoto inventáře jsou betonové stavby různého druhu, ale výjimku tvoří tábory mírových aktivistů u významných vojenských základen druhdy vybavených nukleární výzbrojí. Archeologický obraz, který poskytují výzkumy mírového tábora u atomové raketové základny Greenham Common v Anglii (Fiorato 2009) nebo tábora u zkušební stanice jaderných zbraní v Nevadě (Beck-Drollinger-Schofield 2009), má - asi nikoliv překvapivě - některé shodné rysy s domácími trampskými tábořišti (Vařeka-Symmonds 2013).

Charakteristickými znaky studené války byly dezinformace, mlžení a propaganda (Fairclough 2009, 23). Třicet let československých spartakiád nepochybně náleží k třetímu výše jmenovanému charakteristickému znaku studené války a jejich armádní část tím spíše. Část prostoru někdejšího bělohorského bojiště, dnes Bílé Hory a Vypichu, zaujímaly periodicky téměř vždy po pěti letech spartakiádní tábory Československé lidové armády (1960, 1965, 1975, 1980, 1985).

Armádní část spartakiády měla reprezentovat nejen fyzickou připravenost a vysokou úroveň disciplíny ČSLA pro boj s kapitalistickým nepřítelem, ale měla i hlubší symbolický význam. Armádní skladby měly symbolicky stvrzovat stabilitu a trvanlivost režimu státního socialismu, jejich technická a fyzická náročnost měla odrážet odvahu vojáků ČSLA a jejich odhodlání překonávat protivenství (Roubal 2016, 211-215). V roce 1975 se IV. československé spartakiády účastnilo téměř čtrnáct tisíc vojáků, kteří po měsících nácviků v posádkách nacvičovali ještě další týdny př́imo na Strahově (Roubal 2016, 211). Pro nácvik bylo potřeba zajistit zázemí, které by bylo možno strážit, a vojáky $v$ jeho nitru udržovat v potřebné disciplíně. Toto zázemí tak pravidelně zaujímalo prostor Vypichu až po ohradní zed' obory Hvězda jako vojenský tábor. Kolmý letecký snímek, který vznikl v letních měsících roku 1975, tento tábor velice dobře zachycuje. $\mathrm{Na}$ snímku (obr. 7) je patrná geometrická pravoúhlá organizace vojenského tábora, který se rozprostírá všude kolem křižovatky dnešních ulic Bělohorská, Kukulova a Ankarská. Pravidelná 
uskupení vojenských stanů, v kterých bylo ubytováno mužstvo, jsou doplněna neméně pravidelně uspořádanými autoparky.

Pozůstatky vojenských táborů ČSLA byly zachyceny v průběhu záchranného výzkumu $v$ roce 2010 . S pobytem vojáků ve spartakiádním městečku lze spojovat fragmenty stanových kolíků, ešusů a především vojenských odznaků (obr. 8:1,2). Nálezy tohoto období pochází z prostoru Vypichu při ulici Bělohorská, východním směrem od ulice (obr. 1:5). Jak jsme již zdůraznili $\mathrm{v}$ úvodu tohoto př́spěvku, popisované výsledky výzkumů pocházejí pouze z detektorových průzkumů. V př́ípadě předmětné plochy (obr. 1:5) se jednalo pouze o založení nebo přeložení mlatových, výjimečně asfaltových nebo dlážděných parkových cest při přestavbě parku Ladronka. Průzkum byl proveden pouze $\mathrm{v}$ jejich trasách a nálezy se nacházely prakticky na povrchu, $\mathrm{v}$ drnu anebo těsně pod ním (Bureš ed. 2010b). Bohužel potenciál hmotných pozůstatků vojenských spartakiádních táborů byl identifikován až po ukončení terénní kampaně. V průběhu terénního průzkumu tak byly artefakty jako stanové kolíky a ešusy považovány členy výzkumného týmu za odpad a nebyla jim věnována pozornost. Ta byla v této části výzkumu věnována především mincovním nálezům a případným starším militariím. Do nálezového souboru se tak dostaly pouze dva vojenské odznaky (specialista druhé třídy, inv. č. MMP A 378 490-497, obr. 8:1, a státní znak ČSSR na čepici, inv. č. MMP A 378 490-497, obr. 8:2) a dvě mosazné nábojnice $(50,6 \times 14 \mathrm{~mm}$ a 24,6 × $6 \mathrm{~mm}$, inv. č. MMP A 378 490-497, obr. 8:3, 4). Lokalizace nálezů byla provedena záznamem do plánu. Asi by se archeologická veřejnost necítila ochuzena, pokud by tyto nálezy nebyly zveřejněny vůbec. Má vůbec smysl zabývat se něčím tak nedávným a snažit se zkoumat nálezy, jejichž interpretace se jeví zcela zřejmou? Odpovědí může být skutečnost, že $\mathrm{v}$ posledním - i v tomto př́spěvku citovaném - historickém zpracování československých spartakiád není o organizaci armádních vojenských táborů na Vypichu ani slovo (Roubal 2016). Jistě se může jednat o problém vytěžení archivu ozbrojených složek, ale také mohou platit slova Grahama Fairclougha, který nepochybně, když tato slova formuloval, nevěděl nic o poměrech v někdejší Československé lidové armádě, totiž že ,ne vše, co se v tomto období stalo, bylo zachyceno písemně, a většina dochované dokumentace vykazuje velmi málo objektivity" (Fairclough 2009, 23).

\section{Závěr}

Získané artefakty z období třicetileté války představují jeden z mála souborů archeologických nálezů vztahujících se přímo $\mathrm{k}$ válečným událostem na Bílé hoře. Jak ukazují poznatky shromážděné v tomto krátkém př́spěvku, naše poznání nejen bělohorské bitvy založené hlavně na písemných pramenech je stále možno dále rozšiřovat o další podstatnou vrstvu informací. Totéž, možná v ještě větší intenzitě platí pro archeologický výzkum událostí 20 . století.

Poznatky získané z detektorového průzkumu realizovaného především při zakládání a překládání několika set metrů nově založených a přeložených cest pouze v profilu jejich tras nám neumožňují žádné hlubší interpretace. Význam tohoto př́íspěvku bychom rádi spatřovali v poukázání na dosud nevyčerpaný potenciál nálezů, které se zcela nepochybně ještě v prostoru vyskytují mimo nově založené a přeložené cesty. Tento potenciál by neměl být přehlédnut zejména při budoucích dalších záchranných výzkumech, ale nabízí se i jeho vytěžení výzkumem badatelským.

Vzhledem k vývoji daného území, které je od počátku 20. století radikálně měněno výstavbou rozšiřující se pražské aglomerace, představuje obora letohrádku Hvězda a přilehlé, doposud nezastavěné okolí poslední možnost pro zkoumání nejen bitvy na Bílé hoře, válečného střetu vysokého, faktického i symbolického významu pro české dějiny, ale i pro další výzkum archeologie studené války. $Z$ tohoto hlediska by i př́padný budoucí badatelský výzkum byl v důsledku výzkumem záchranným. 


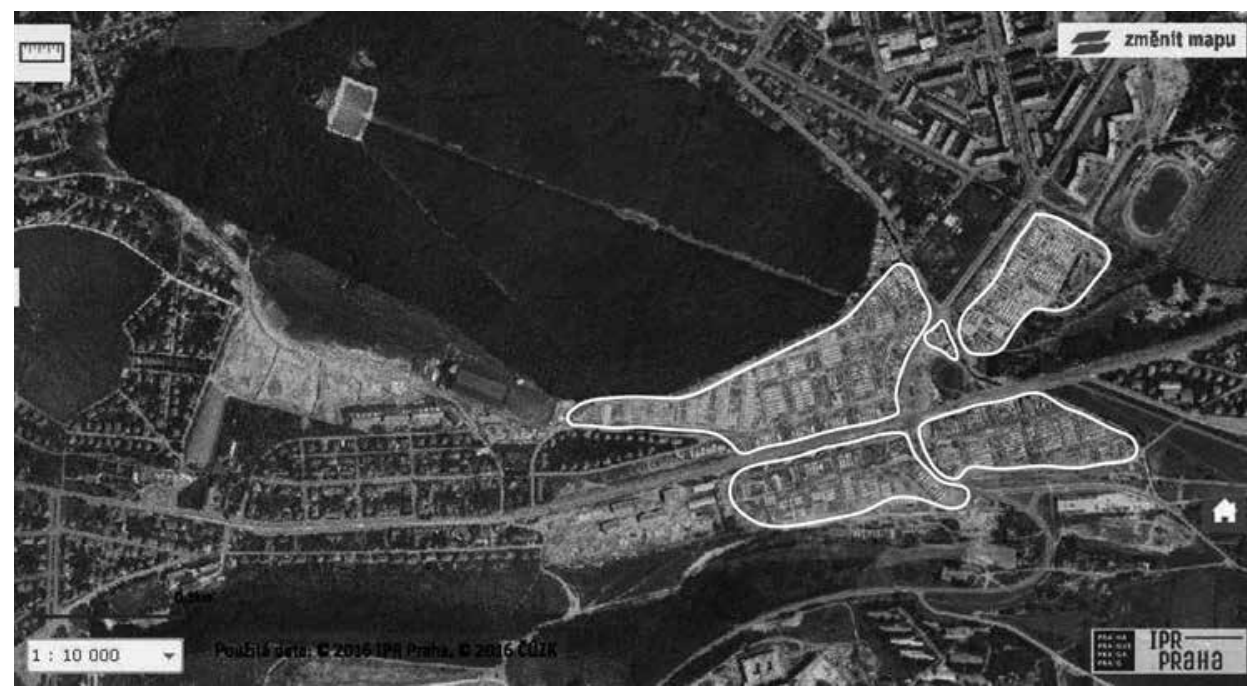

Obr. 7. Spartakiádní vojenský tábor na kolmém leteckém snímku z roku 1975. Dostupné z: http://mpp.praha.eu/ OrtofotoArchiv/.

Abb. 7. Militärlager der Spartakiade auf einem Senkrecht-Luftbild aus dem Jahr 1975. Verfügbar unter: http://mpp.praha. eu/OrtofotoArchiv/.

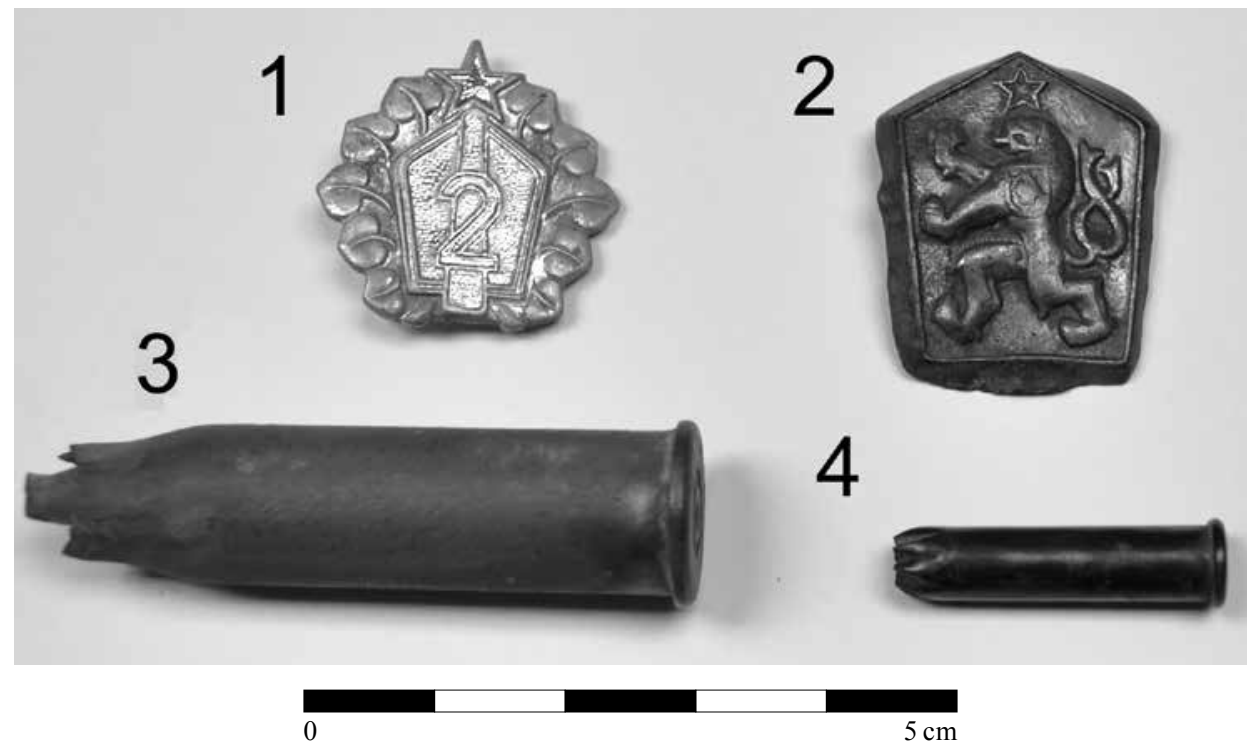

Obr. 8. Odznaky ČSLA. 1 - specialista druhé tř́ídy; 2 - státní znak na čepici; 3 a 4 - mosazné nábojnice; plocha 5. Abb. 8. Abzeichen der Tschechoslowakischen Volksarmee. 1 - Spezialist zweiter Klasse; 2 - Staatswappen für Mützen; 3 und 4 - Messingpatronenhülsen; Fläche 5. 


\section{Prameny a literatura}

AUGÉ, M., 1995: Non-Places: Introduction to an Anthropology of Supermodernity. London.

BECK, C. M.-DROLLINGER, H.-SCHOFIELD, J., 2009: Archaeology of dissent: Landscape and symbolism at the Nevada Peace Camp. In: A Fearsome Heritage. Diverse Legacies of The Cold War (Schofield, J.-Cocroft, W., edd.), 297-320. Walnut Creek.

BENEŠ, J.-KUBŮ, F.-TÖRÖK, J., 1995: Soubor militarií z počátku třicetileté války z Volarských šancí, AR XLVII, 461-480.

BITVA U RAKOVNÍKA 1620, 2011: Bitva u Rakovníka. Rakovník.

BOULTON, A., 2009: Good bay Forst Zinna. In: A Fearsome Heritage. Diverse Legacies of The Cold War (Schofield, J.-Cocroft, W., edd.), 181-192. Walnut Creek.

BUCHLI, V.-LUCAS, G., 2001: Archaeologies of the Contemporary Past. Abingdon.

BUREŠ, M., 2013: Zaniklá kulturní krajina Novohradských hor - Deserted cultural landscape of Novohradské hory. In: Archeologické prospekce a nedestruktivní archeologie v Jihočeském kraji, kraji Vysočina, Jihomoravském kraji a v Dolním Rakousku. Archeologické výzkumy v jižních Čechách Supplementum 9 (Chvojka, O., ed.), 27-42. České Budějovice.

- 2015: Vesnice zaniklé po roce 1945 a kulturní krajina Novohradských hor - Villages Extinct after 1945 and the Cultural Landscape of the Novohradské Mountains. Plzeň.

BUREŠ, M., ed., 2010: Nálezová zpráva ze záchranného archeologického výzkumu provedeného při stavební činnosti „3 bytové domy pro seniory“. Č́slo akce Archeo Pro: 39/08 AP. Nepublikovaná nálezová zpráva ulož. v archivu Archeo Pro o.p.s.

- 2010a: Nálezová zpráva ze záchranného archeologického výzkumu provedeného při stavební činnosti „Cyklo Markétská - Staré náměstí, Praha 6“. Číslo akce Archeo Pro: 77/10 AP. Nepublikovaná nálezová zpráva ulož. v archivu Archeo Pro o.p.s.

- 2010b: Nálezová zpráva ze záchranného archeologického výzkumu provedeného při stavební činnosti „Areál volného času Ladronka II. a III. etapa“. Č́íslo akce Archeo Pro: 1/10 AP. Nepublikovaná nálezová zpráva ulož. v archivu Archeo Pro o.p.s.

- 2011: Nálezová zpráva ze záchranného archeologického výzkumu provedeného při stavební činnosti „Novostavba mateřské školy Bílá Hora“. Č́slo akce Archeo Pro: 91/10 AP. Nepublikovaná nálezová zpráva ulož. v archivu Archeo Pro o.p.s.

COCROFT, W., 2009: Defining the national archaeological character of Cold War remains. In: A Fearsome Heritage. Diverse Legacies of The Cold War (Schofield, J.-Cocroft, W., edd.), 107-127. Walnut Creek.

FAIRCLOUGH, G., 2009: The Cold War in context: Archaeological explorations of private, public and political complexity. In: A Fearsome Heritage. Diverse Legacies of The Cold War (Schofield, J.Cocroft, W., edd.), 19-32. Walnut Creek.

FATKOVÁ, G. a kol., 2014: Tachovsko: krajina v paměti / pamět' v krajině. Plzeň.

FEVERSHAM, P.-SCHMIDT, L., 2009: The Berlin Wall: Border fragment, world heritage? In: A Fearsome Heritage. Diverse Legacies of The Cold War (Schofield, J.-Cocroft, W., edd.), 193-209. Walnut Creek.

FIORATO, V., 2009: Greenham Common: The conservation and management of a Cold War archetype. In: A Fearsome Heritage. Diverse Legacies of The Cold War (Schofield, J.-Cocroft, W., edd.), 129-154. Walnut Creek.

FORBELSKÝ, J., 2006: Španělé, ̌̌íše a Čechy v 16. a 17. století. Praha.

FUNK, L., 2013: Vesnice zaniklé po roce 1945. In: Archeologie 19. a 20. století. Přístupy - metody témata (Vařeka, P., ed.), 23-28. Plzeň.

FUNK, L.-VÁŇA, M., 2012: Datování objektů zaniklých po roce 1945 pomocí dendrochronologie živých stromů - Die Datierung von nach 1945 aufgegebenen Objekten mithilfe der Dendrochronologie lebender Bäume, AH 37, 799-807.

GONZÁLEZ-RUIBAL, A., 2008: Time to Destroy. An Archaeology of Supermodernity, Current Anthropology 49, No. 2, 247-279. DOI: https://doi.org/10.1086/526099

HARRISON, R.-SCHOFIELD, J., 2010: After Modernity. Archaeological Approaches to the Contemporary Past. Oxford.

HAVEL, J., 1980: Hromadný hrob bělohorských bojovníků - Ein Massengrab der Krieger vom Weißen Berg (Bílá hora), Archaeologia Pragensia I, 227-231. 
HOLTORF, C.-PICCINI, A., edd., 2011: Contemporary Archaeologies: Excavating Now. Frankfurt am Main.

CHALINE, O., 2013: Bílá hora. Praha.

JÁNSKÁ, E., 1966: Hromadný hrob bělohorských bojovníků, Staletá Praha 2, 107-110.

KLUČINA, P., 2000: Třicetiletá válka. Obraz doby 1618-1648. Praha - Litomyšl.

Letecký snímek Prahy z roku 1975, http://mpp.praha.eu/OrtofotoArchiv/.

MANDZY, A., 2015: On the frontiers of Europe, not all musket balls were round; accuracy and penetration of various types of military small arms munition from the mid seventeenth century to the early eighteenth century, Journal of Conflict Archaeology 10, No. 3, 154-176. DOI: https://doi.org/10.1080 $/ 15740773.2016 .1181855$

MATOUŠEK, V., 2000: Graffiti ve světle archeologie. Př́íspěvek k diskusi o archeologii současnosti, Cargo 2, č. 1, 4-17.

- 2006: Třebel. Obraz krajiny s bitvou. Praha.

- 2013: Předběžná zpráva o 2. a 3. sezoně archeologického výzkumu bojiště u Rozvadova z roku 1621. In: Sborník Muzea Českého lesa v Tachově 33, 3-14. Domažlice.

MATOUŠEK, V. a kol., 2011: Zpráva o první sezoně systematického archeologického výzkumu bojiště z roku 1621 u Rozvadova. In: Sborník Muzea Českého lesa v Tachově 32, 3-14. Domažlice.

MATOUŠEK, V.-KÖSSL, A.-ŠIMEK, J., 2010: Bitva na Bílé hoře na rytinách Jana Sadelera a v Theatru Europaeu. In: Ecce Homo. In memoriam Jan Fridrich (Semrádová, K.-Fridrichová-Sýkorová, I., edd.), 224-238. Praha.

MAŠEK, N., 1960: Nálezová zpráva ze záchranného archeologického výzkumu provedeného při stavební činnosti „Výkopové práce Vojenské správy ČSLA“. Nepublikovaná nálezová zpráva č. 1825/60 ulož. v archivu ARÚ AV ČR, Praha, v. v. i.

MUCHKA, I. P.-PURŠ, I.-DOBALOVÁ, S.-HAUSENBLASOVÁ, J., 2014: Hvězda - arcivévoda Ferdinand Tyrolský a jeho letohrádek v evropském kontextu. Praha.

NEUSTUPNÝ, E., 2013: Archeologie modernity - teoretický kontext. In: Archeologie 19. a 20. století. Př́istupy - metody - témata (Vařeka, P., ed.), 13-16. Plzeň.

RAK, M., 2011: Možnosti archeologického poznání novodobých polních fortifikací na př́íladu lokality z 30. let 20. století - Möglichkeiten der archäologischen Erforschung neuzeitlicher Feldbefestigungen am Beispiel einer Fundstelle aus den dreißiger Jahren des 20. Jahrhunderts, AH 36, 279-288.

- 2014: Archeologie konfliktů 20. století - Aeroarcheologie. Historie - témata - metody - př́́klady. Plzeň.

RAK, M.-FUNK, L.-VÁŇA, M., 2012: Vesnice v zajetí železné opony. Možnosti archeologického poznání studené války, Antropowebzin 3, 241-251.

RAK, M.-STARKOVÁ, L.-FUNK, L., 2014: Relikty „Studené války“ jako součást kulturní historie, Veřejná archeologie 7, 42-61.

PEKAŘ, J., 1921: Bílá hora. Její prŕíčiny i následky. Praha.

PETRÁŇ, J., 1972: Staroměstská exekuce: Několik poznámek z dějin povstání feudálních stavů proti Habsburkům v letech 1618-1620. Praha.

POLIŠENSKÝ, J., 1951: Současný stav bádání o Bílé hoře, ČMM LXX, 1-25.

ROUBAL, P., 2016: Československé spartakiády. Praha.

RYTÍŘ, L., ed., 2015: Nálezová zpráva ze záchranného archeologického výzkumu provedeného při stavební činnosti „Obnova cestní sítě Hvězda - rekonstrukce středového průhledu a etapa 0 “. Číslo akce Archeo Pro: 79/15 AP. Nepublikovaná nálezová zpráva ulož. v archivu Archeo Pro o.p.s.

- 2015a: Nálezová zpráva ze záchranného archeologického výzkumu provedeného př̀i stavební činnosti „Rekonstrukce kamenné zdi v oboře Hvězda“. Číslo akce Archeo Pro: 91/15 AP. Nepublikovaná nálezová zpráva ulož. v archivu Archeo Pro o.p.s.

SCHOFIELD, J., 2005: Combat Archaeology. London.

SMETÁNKA, Z., 1967: Nálezová zpráva ze záchranného archeologického výzkumu provedeného při stavební činnosti „Záchranný archeologický výzkum na Bílé hoře - Praha západ, 22. 4. 1955“. Nepublikovaná nálezová zpráva č. 6642/67, ulož. v archivu ARÚ AV ČR, Praha, v. v. i.

SKALNÍK, M., 2012: Dělostřelectvo v první polovině 17. století. Nepublikovaná bakalářská práce, Historický ústav, Filozofická fakulta, Masarykova univerzita, Brno.

SKÁLA, P., ed., 2001: Obora hvězda, historická studie. Louňovice.

SPURNÝ, V., 1978: Nálezová zpráva o „Nálezu koster v Praze Břevnově, Zeyerova alej ppč. 1449““. Nepublikovaná nálezová zpráva č. 2750/78, ulož. v archivu ARÚ AV ČR, Praha, v. v. i. 
ŠÁMAL, Z., 2011: Archeologové na bojišti. In: Bitva u Rakovníka 1620, 50-60. Rakovník.

TAPIÉ, V. L., 1936: Bílá hora a francouzská politika. Praha.

UHLÍŘ, D., 1998: Černý den na Bílé hoře 8. listopadu 1620. Brno.

VAŘEKA, P.-SYMMONDS, J., 2013: Archeologie trampingu na př́íkladu výzkumu „Kachního údoli““ u Stř́bra (Plzeňský kraj). In: Archeologie 19. a 20. století. Př́ístupy - metody - témata (Vařeka, P., ed.), 137-164. Plzeň.

VÁŇA, M., 2016: Archeologie vesnic zaniklých z důvodu výstavby vodních nádrží. Plzeň.

WALDHAUSER, J., 2009: Švédský vojenský tábor za třicetileté války na katastrech Staré Boleslavi (okr. Praha - východ) a Hlavence (okr. Mladá Boleslav), ASČ 13, 939-964.

\section{Zusammenfassung}

\section{Der Weiße Berg - ein Schlachtfeld des Dreißigjährigen und des Kalten Krieges}

Die im vorliegenden Beitrag bearbeiteten archäologischen Daten wurden Dank eines in den Jahren 2008-2015 systematisch durchgeführten Monitorings aller in der Oberfläche der durchweg urbanen Landschaft des Weißen Bergs getätigten baulichen Eingriffe gewonnen.

Die unter den gemachten Funden größte Gruppe bilden Musketenkugeln bzw. Munition von anderen Vorderladern. Ihr Kaliber bewegt sich zwischen 11 und $17 \mathrm{~mm}$ (Abb. 2). Weitere Funde stellen Knöpfe, Bruchstücke von Beschlägen und verschiedene Schnallen dar, die Ausrüstungsbestandteile zeitgenössischer Soldaten sein könnten (Abb. 3). Bei der Rekonstruktion der nördlichen (nordöstlichen) Mauer des Wildgeheges wurde auch eine Eisenkugel entdeckt, die wahrscheinlich zu einer leichteren dreipfündigen Feldkanone - einem Falkonett oder einer Regimentskanone - gehörte (Abb. 1:6; 4, dazu Skalník 2012, 15).

Das jeweilige Kaliber der entdeckten Schusswaffenkugeln entspricht auch der Beschreibung und dem Verlauf der Schlacht, als es am rechten Flügel vor allem zu Scharmützeln der Kavallerie und schließlich zur Verfolgung die Ständearmee kam, dies ebenfalls hauptsächlich durch die kaiserlich-ligistische Kavallerie. Die Kavallerie verwendete überwiegend lange Reiterpistolen mit Feuerschloss, deren Kaliber sich ungefähr zwischen 10-13 mm bewegte (Abb. 2:6). Eine weitere Reiterwaffe war die Arkebuse mit einem Kaliber von um die ungefähr 15 mm (Abb. 2:4, 5). Die Musketen der Infanterie hatten ein Kaliber zwischen 17 und $25 \mathrm{~mm}$ (Abb. 2:1-3), am üblichsten waren jedoch 19-20 mm (Matoušek 2006, 135-136; Šámal 2011, 54).

Die Gruppe der entdeckten Kugeln deutet somit eher auf kleinere Kaliber von Reiterwaffen hin und stimmen so mit den zeitgenössischen Beschreibungen der Schlacht überein, von denen gerade die Kämpfe der Artillerie vor allem am rechten Flügel der Ständearmee in den Bereich südlich und südöstlich von der Einfriedungsmauer des Wildgeheges (Abb. 1:1,2) und die anschließenden Kämpfe dann direkt an der Mauer (Abb. 1:2, 3) angesiedelt werden. Die aus dem Raum des Wildgeheges stammenden Funde können dann mit der letzten Phase der Schlacht zusammenhängen, als die Truppen des Weimarer Regiments und der königlichen Garde im Wildgehege umzingelt und niedergemetzelt oder gefangen genommen wurden (Abb. 1:4). Funde, die aus dem Bereich der Ebene Na Vypichu stammen (Abb. 1:5) können wir eher mit der flüchtenden Ständearmee in Verbindung bringen.

Ein Teil des Raums des ehemaligen Schlachtfeldes vom Weißen Berg (heute Bílá hora und $\mathrm{Na}$ Vypichu) wurde periodisch fast immer alle fünf Jahre von den von der Tschechoslowakischen Volksarmee für die Spartakiaden errichteten Militärlagern (1960, 1965, 1975, 1980, 1985) eingenommen. Im Jahr 1975 haben fast vierzehntausend Soldaten an der IV. tschechoslowakischen Spartakiade teilgenommen, die nach monatelangen Übungen in den Garnisonen noch weitere fünf Wochen direkt auf dem Berg Strahov Übungen durchführten (Roubal 2016, 211). Auf einem den Sommermonaten des Jahres 1975 entstandenen Senkrecht-Luftbild wird dieses Lager sehr gut dargestellt. Auf der Aufnahme (Abb. 5) ist die geometrische rechtwinklige Organisation des Militärlagers zu sehen, die sich überall um die Kreuzung der heutigen Straßen Bělohorská, Kukulova und Ankarská herum erstreckt. Mit dem Aufenthalt der Soldaten in dem Spartakia- 
denstädtchen können Fragmente von Zeltheringen, Essschüsseln und vor allem Militärabzeichen in Verbindung gebracht werden (Abb. 6). Die Funde aus diesem Zeitraum konzentrierten sich in dem Raum von der Ebene Na Vypichu in östlicher Richtung bis zur Ansiedlung Ladronka (Abb. 1:5).

PhDr. Michal Bureš, Ph.D., Archeo Pro o.p.s., Zlatnická 11, 11000 Praha 1, Česká republika, michal.bures@archeo4u.cz

Mgr. Ladislav Rytír, Archeo Pro o.p.s., Zlatnická 11, 11000 Praha 1, Česká republika, ladislav.rytir@archeo4u.cz 
